\title{
Soil Physical Attributes Under Eucalyptus stands With Non-living and Living Plants
}

\author{
Nayana Alves Pereira ${ }^{1}$, João Carlos Medeiros ${ }^{2}$, Julian Júnio de Jesus Lacerda ${ }^{3}$, Jaqueline Dalla Rosa ${ }^{2}$, \\ Bruna Anair Souto Dias ${ }^{3}$, Everaldo Moreira da Silva ${ }^{3}$, Rafael Felippe Ratke ${ }^{4} \&$ Wanderson de Sousa Mendes ${ }^{1}$ \\ ${ }^{1}$ Graduate Program of Soil and Plant Nutrition, "Luiz de Queiroz" College of Agriculture, University of São Paulo, \\ Piracicaba, São Paulo, Brazil \\ ${ }^{2}$ Formation Center of Science and Agroforestry Technologies, Federal University of Southern Bahia, Itabuna, \\ Bahia, Brazil \\ ${ }^{3}$ Campus Professora Cinobelina Elvas, Federal University of Piaú, Bom Jesus, Piaui, Brazil \\ ${ }^{4}$ Campus Chapadão do Sul, Federal University of Mato Grosso do Sul, Chapadão do Sul, Mato Grosso do Sul, \\ Brazil \\ Correspondence: Nayana Alves Pereira, Graduate Program of Soil and Plant Nutrition, "Luiz de Queiroz" College \\ of Agriculture, University of São Paulo, Piracicaba, São Paulo, Brazil. Tel: 55-199-8185-4876. E-mail: \\ nayanaalves.esalq@usp.br
}

Received: November 5, 2018

Accepted: December 9, 2018 Online Published: February 15, 2019

doi:10.5539/jas.v11n3p197

URL: https://doi.org/10.5539/jas.v11n3p197

\begin{abstract}
The conservation of ecosystems has benefited from planted forests which provide reforested wood reducing the pressure on deforestation of natural forests. Soil physical attributes determine soil water storage capacity; therefore, they play an important role on plant roots' development which may compromise plant's survival. The study tested the influence of soil physical and water attributes on the survival of Eucalyptus spp. clones under dry tropical climate. Two areas were selected, including one with living plants and a second with non-living plants of Eucalyptus spp. clones. Moreover, five soil profiles were studied in each area and the parameters estimated were soil bulk density, total porosity, saturated hydraulic conductivity, soil water retention curve, pores size distribution, available water capacity, and S index. Soil physical and hydric attributes did not differ between the area with living plants and the one with non-living plants. The saturated hydraulic conductivity in the area surface layer was high for both the living plants and non-living palnts; $331 \mathrm{~mm} \mathrm{~h}^{-1}$ and $294 \mathrm{~mm} \mathrm{~h}^{-1}$, respectively. The $\mathrm{S}$ index (to give the value) indicated that the structure was suitable for the development of Eucalyptus trees. Furthermore, it was possible to affirm that soil physical and water attributes of the studied areas were promising for the cultivation of Eucalyptus spp. in the dry tropical climate.
\end{abstract}

Keywords: soil structure, water stress, pores size distribution, available water capacity

\section{Introduction}

The forest industry is recognized for its sustainable, social, and economic importance. Planted trees help conserving ecosystems because they reduce the deforestation pressure on natural forests leading to reforestation of degraded areas (Souza et al., 2014).

The total area of planted trees for industrial purposes in Brazil reached 7.8 million of hectares in 2016 (Brazilian Tree Industry, 2017). The Eucalyptus trees occupy 5.56 million of hectare of that total $(71.3 \%)$, mainly spatialized in the states of Minas Gerais (25.2\%), Sao Paulo (17.6\%), and Mato Grosso do Sul (14.5\%). Brazil has a great potential for cultivation of forest crops, mainly Eucalyptus species.

According to the Brazilian Tree Industry (2017), the Brazilian Cerrado biome, in the state of Piauí, is placed at the $15^{\text {th }}$ position among planted forest areas in Brazil with 37,176 hectares of Eucalypus spp. Some factors have contributed to the Eucalyptus cultivation in this region, such as well-drained and deeper soils adapted to mechanization. Moreover, another positive factor is the seasonal climate with half-year dry season and half-year wet season (Lopes, 2013). 
Eucalyptus' productivity is conditioned by many elements and one of the most important is the water supply (Ryan et al., 2010) because soil water availability cause direct and indirect effects on the development of trees (Vose \& Swank, 1994). The three first years of Eucalyptus forest development are the most critical in its life cycle because of its initial high demand for water. However, the water demand decreases as a consequence of soil type, local conditions, regional rainfall and management practices (Oleriano \& Dias, 2007). Furthermore, water deficit may compromise physiological growth of Eucalyptus species leading, in some cases, to their death.

Forest areas planted with Eucalyptus in the state of Piauí are relatively recent and have grown in recent years (Fernandes et al., 2012; Ibiapina et al., 2014). However, the death of adult Eucalyptus trees has become a recurrent problem. The premature senescence occurs due to soil water deficiency which directly influences forest productivity and indirectly agricultural areas. The soil physical conditions regulate water retention levels in soil micropores; therefore, they impact on plants root development. Studies to evaluate soil physical attributes and soil water retention capacity became necessary. For that reason, this work evaluated the influence of soil physical and water attributes on the survival of Eucalyptus spp. clones.

\section{Materials and Methods}

The study was conducted on commercial fields of Eucalyptus at Real Agropecuária Farm (6 $6^{\circ} 14^{\prime} 16^{\prime \prime} \mathrm{S} ; 42^{\circ} 41^{\prime} 18^{\prime \prime}$ W), Regeneração city, PI. The climate was classified as tropical with dry periods. The rainy season was from October to April and the rainiest quarter occured from January to March with the possibility of dry periods (Andrade et al., 2011). The average meteorological data of the study area, for over 45 years, were obtained from the Brazilian National Institute of Meteorology (INMET, its acronym in Portuguese) over a period of 10 years according to Penman-Monteith method which evaluate the value of ETo at $6.0 \mathrm{~mm} \mathrm{~d}^{-1}$.

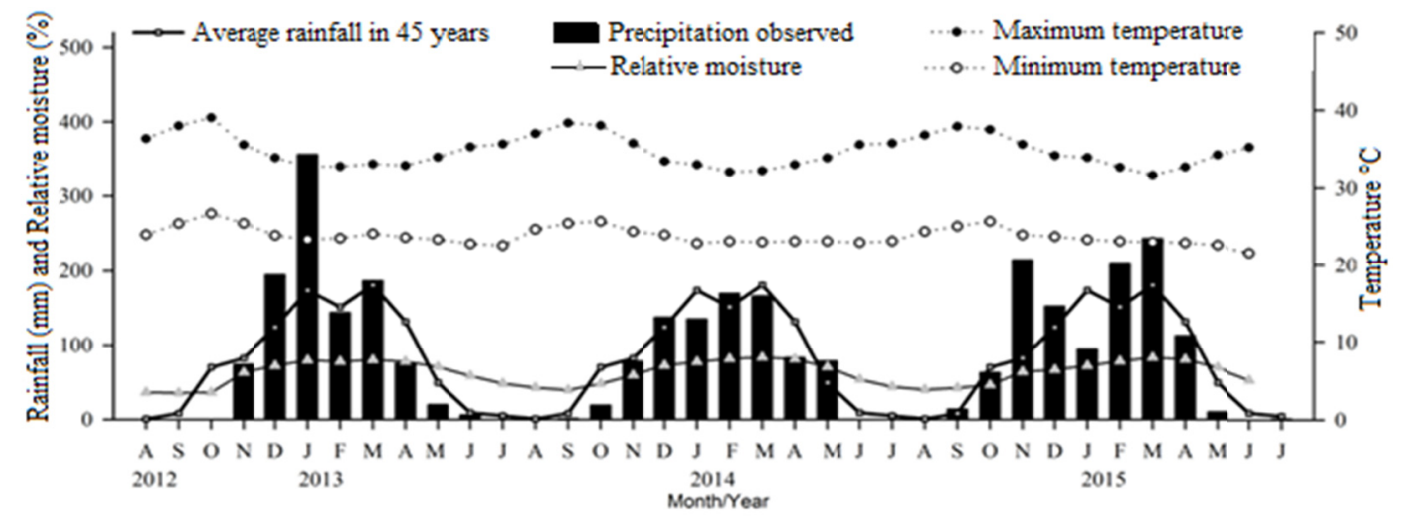

Figure 1. Historical meteorological data for the city of Floriano-PI

Afterwards, the crop coefficient $(\mathrm{Kc})$ of 0.82 was used to convert the ETo to ETc from the evapotranspiration of Eucalyptus planted area (Alveset al., 2013). The crop evapotranspiration (ETc) was calculated according to the Equation (1):

$$
\mathrm{ETc}=\mathrm{ETo} \times \mathrm{Kc}
$$

where, ETc is the crop evapotranspiration; ETo is the reference evapotranspiration; $\mathrm{Kc}$ is the crop coefficient.

The soil profiles were described and classified as medium texture Oxisol (Santoset al., 2015). The chemical characterization of the soil was shown in Table 1 . The relief was relatively flat with an altitude between 400 and $500 \mathrm{~m}$. Soil texture was sandy-loam. Soil acidity was reduced by applying $2 \mathrm{t} \mathrm{ha}^{-1}$ of limestone before planting the seedlings. Then, a subsoiling was made up to $0.60 \mathrm{~m}$ depth and pits were placed at these subsoiling lines. A preplanting fertilization was done with $400 \mathrm{~kg} \mathrm{ha}^{-1}$ of single superphosphate and $130 \mathrm{~kg} \mathrm{ha}^{-1}$ of 06-30-06 (N-P-K) fertilizer. Top dressing fertilization was applied 6 and 12 months after planting with $110 \mathrm{~kg} \mathrm{ha}^{-1}$ of 20-00-20 fertilizer. The weed control was carried out once a year with mechanical mowing. Eucalyptus spp. seedlings were planted with $3 \times 2 \mathrm{~m}$ of spacing between plants and $3.5 \times 3.0 \mathrm{~m}$ among lines in January 2012 . 
Table 1. Soil chemical properties of the two study areas

\begin{tabular}{|c|c|c|c|c|c|c|c|c|c|c|}
\hline Layers & $\mathrm{pH}$ & $\mathrm{P}$ & $\mathrm{K}$ & $\mathrm{Ca}$ & $\mathrm{Mg}$ & $\mathrm{Al}$ & $\mathrm{H}+\mathrm{Al}$ & SB & $\mathrm{V}$ & OM \\
\hline 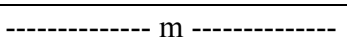 & $\left(\mathrm{H}_{2} \mathrm{O}\right)$ & \multicolumn{2}{|c|}{----- $\mathrm{mg} \mathrm{dm}^{-3}$----- } & \multirow{2}{*}{\multicolumn{6}{|c|}{----------- $\mathrm{cmol}_{\mathrm{c}} \mathrm{dm}^{-3}$------------- $\%$}} & dag $\mathrm{kg}^{-1}$ \\
\hline Area with dead plants & & & & & & & & & & \\
\hline $0-0.10$ & 4.0 & 4.2 & 0.19 & 2.88 & 0.77 & 0.73 & 13.2 & 3.84 & 21.6 & 3.73 \\
\hline $0.20-0.40$ & 3.9 & 2.0 & 0.06 & 2.16 & 0.41 & 0.77 & 11.7 & 2.63 & 17 & 3.33 \\
\hline $0.40-0.60$ & 3.9 & 1.3 & 0.05 & 2.59 & 0.40 & 0.57 & 10.0 & 3.04 & 22.3 & 2.40 \\
\hline \multicolumn{11}{|l|}{ Area with living plants } \\
\hline $0-0.10$ & 3.5 & 3.0 & 0.12 & 1.95 & 0.35 & 0.97 & 13.5 & 2.42 & 14.3 & 4.27 \\
\hline $0.20-0.40$ & 3.6 & 2.4 & 0.10 & 2.54 & 0.36 & 0.70 & 12.2 & 3.00 & 8.04 & 3.97 \\
\hline $0.40-0.60$ & 3.7 & 1.2 & 0.04 & 2.47 & 0.39 & 0.60 & 9.8 & 2.90 & 21.8 & 2.47 \\
\hline
\end{tabular}

Note. $\mathrm{pH}=$ hydrogen potential; $\mathrm{P}=$ phosphorus; $\mathrm{K}=$ potassium; $\mathrm{Ca}=$ calcium; $\mathrm{Mg}=$ magnesium; $\mathrm{Al}=$ aluminium; $\mathrm{H}+\mathrm{AL}=$ hydrogen+aluminium; $\mathrm{SB}=$ sum of bases; $\mathrm{V}=$ saturation/base; $\mathrm{OM}=$ organic matter.

On February 2015, three years after planting, two areas were randomly chosen to evaluate their soil physical and hydric attributes. In the first, Eucalyptus plants were alive and in the second area, they were dead. The selection process was based on the following criteria: (i) area with living plants, all plants around were alive; (ii) area with dead plants, all plants around were dead. Disturbed and undisturbed samples were collected from five soil profiles of both the areas with and without living plants. The distance between these profiles was approximately $5 \mathrm{~m}$. Soil sampling was carried out at $0-0.10,0.10-0.20,0.20-0.40,0.40-0.60,0.60-1.0$ and 1.0 to $2.0 \mathrm{~m}$ depths and both the undisturbed and disturbed samples.

Physical analysis of granulometric distribution and particle density (Dp) were performed on disturbed samples. The granulometric analysis was performed using the pipette method (Gee \& Bauder, 1986) and the particle density using the volumetric balloon method (Blake \& Hartge, 1986b).

Table 2. Soil physical properties of the area with non-living plants and of the area with living plants

\begin{tabular}{|c|c|c|c|c|}
\hline Layers & Sand & Silt & Clay & $\mathrm{Dp}$ \\
\hline -------------------- m ------------------- & ------- & $-----\xi$ & ------------------- & $---\mathrm{Mg} \mathrm{m}^{-3}-\cdots$ \\
\hline \multicolumn{5}{|l|}{ Area with non-living plants } \\
\hline $0-0.10$ & 570 & 130 & 300 & 2.56 \\
\hline $0.10-0.20$ & 560 & 140 & 300 & 2.60 \\
\hline $0.20-0.60$ & 550 & 150 & 300 & 2.66 \\
\hline $0.60-1.0$ & 570 & 160 & 270 & 2.72 \\
\hline $1.0-2.0$ & 580 & 160 & 260 & 2.72 \\
\hline CV $(\%)$ & 1.13 & 6.25 & 2.64 & 2.52 \\
\hline DP & 0.64 & 0.90 & 0.77 & 0.07 \\
\hline \multicolumn{5}{|l|}{ Area with living plants } \\
\hline $0-0.10$ & 570 & 130 & 300 & 2.53 \\
\hline $0.10-0.20$ & 560 & 140 & 300 & 2.57 \\
\hline $0.20-0.60$ & 550 & 150 & 300 & 2.64 \\
\hline $0.60-1.0$ & 570 & 140 & 280 & 2.69 \\
\hline $1.0-2.0$ & 550 & 150 & 300 & 2.69 \\
\hline CV (\%) & 1.23 & 6.09 & 2.71 & 2.50 \\
\hline DP & 0.69 & 0.86 & 0.80 & 0.07 \\
\hline
\end{tabular}

Soil bulk density (Ds), total porosity (TP), soil water retention curve (WRC), soil hydraulic conductivity (Ksat), available soil water capacity (WRC) and S index (obtained at the inflection point of water retention curve) were determined from undisturbed samples. Soil bulk density was determined by volumetric ring method (Blake \& Hartge, 1986a). Total porosity was function of soil bulk density (Ds) and particle density (Dp), through Equation (2).

$$
\mathrm{TP}=1-\mathrm{Ds} / \mathrm{Dp}
$$


WRC was determined on undisturbed and saturated samples submitted to the follwoing matrix potentials: $-0,-10$, $-33,-70,-100,-500$, and $-1500 \mathrm{kPa}$, using Richards pressure chamber with porous plate (Kluteet al., 1986). At stability, the samples were weighted to quantify their moisture content at each applied potential. At the end of the last potential applied $(-1500 \mathrm{kPa})$, the samples were dried in an oven at $105^{\circ} \mathrm{C}$ for 24 hours to determine their dry soil mass and gravimetric moisture. The soil WRC was obtained by adjusting the dataset to van Genuchten's model using the Retention Curve software (RETC) (van Genuchten, 1980) (Equation 3):

$$
\theta=\left(\theta_{\text {sat }}-\theta_{\text {res }}\right)\left[1+(\alpha h)^{\mathrm{n}}\right]^{-\mathrm{m}}+\theta_{\text {res }}
$$

where, $\theta$ corresponds to soil volumetric moisture, $\theta_{\text {sat }}$ and $\theta_{\text {res }}$ are soil water contents representing saturation and residual moisture, respectively; $\mathrm{h}=$ soil water matrix potential $(\mathrm{kPa}) ; \alpha, \mathrm{n}$ and $\mathrm{m}$ are empiracal parameters of the model in which $\mathrm{m}$ and $\mathrm{n}$ are coefficients and $\alpha$ in $\mathrm{kPa}$.

Pore size distribution was calculated from WRC data according to (Boumaet al., 1977) classification proposal (Table 3).

Table 3. Soil pore classification based on size distribution

\begin{tabular}{lll}
\hline Category & Pore diameter $(\mu \mathrm{m})$ & Pore radius $(\mu \mathrm{m})$ \\
\hline Macropores & $100-5000$ & $50-2500$ \\
Mesopores & $30-100$ & $15-50$ \\
Micropores & $0.002-30$ & $0.001-15$ \\
\hline
\end{tabular}

Pore size distribution was obtained based on the retention curve calculated by the equivalent radius on each potential (Libardi, 2012), as shown in Equation (4).

$$
\mathrm{r}=(2 \cdot \sigma \cdot \cos \varphi) /(\rho \mathrm{sol} \cdot \mathrm{g} \cdot \mathrm{h})
$$

where, $\mathrm{r}$ is the pore radius equal to 50,15 and $1 \mu \mathrm{m} ; \sigma$ is the surface water tension at $0.072 \mathrm{~N} \mathrm{~m}^{-1} ; \varphi$ is the contact angle between water and pore wall equal to $0 ; \rho s o l$ is the solution density, that is $1000 \mathrm{~kg} \mathrm{~m}^{-3}$; $\mathrm{g}_{\text {is }}$ the gravity acceleration, $9.8 \mathrm{~m} \mathrm{~s}^{-2}$; and $\mathrm{h}$ is the water column height (applied potential).

Pore percentage with upper diameter was calculated for each potential using Equation (5):

$$
\mathrm{P}=100 \times[1-(\mathrm{TP}-\theta) / \mathrm{TP}]
$$

where, $\mathrm{P}$ is the soil pore percentage with upper diameter calculated to each potential; TP is the total soil porosity (\%); $\theta$ is the Ksat which was determined by descending loading method (Reynolds et al., 2002) decribed in Equation (6):

$$
\mathrm{Ksat}=\left(\frac{\phi}{\phi \mathrm{s}}\right)^{2}\left(\frac{\mathrm{L}}{\mathrm{t}}\right) \operatorname{Ln}\left(\frac{\mathrm{h} 0}{\mathrm{~h} 1}\right)
$$

where, $\phi$ is the cylindrical ring diameter without soil; $\phi$ s is the ring diameter with soil; $L, h_{0}$ and $h_{1}$ are the height; $\mathrm{t}$ is time.

$\mathrm{S}$ index or WRC inclination value at the inflection point was determined based on the parameters obtained from retention curve, according to Dexter (2004)'s Equation (7):

$$
\mathrm{S}=-\mathrm{n} \cdot(\theta \mathrm{s}-\theta \mathrm{r}) \cdot[1+1 / \mathrm{n}]^{-(1+\mathrm{m})}
$$

where, $\theta \mathrm{s}$ is the soil water content at saturation point on gravimetric basis $\left(\mathrm{kg} \mathrm{kg}^{-1}\right)$; $\theta \mathrm{r}$ is the residue water content $\left(\mathrm{kg} \mathrm{kg}^{-1}\right) ; \mathrm{n}$ and $\mathrm{m}$ are the retention curve empirical parameters.

Later on, available soil water capacity (WRC) was calculated as a difference between soil water content at -10 and $-1500 \mathrm{kPa}$ potential multiplied by the soil bulk density and the thickness of each layer studied. Data was submitted to Shapiro-Wilk normality test at $5 \%$ probability. Then, soil hydric and physical attributes from the soil profiles were statistically compared by the paired $t$-test at $5 \%$ of probability.

\section{Results and Discussion}

Soil bulk density (Ds) had no significant difference between the area with living plants and that of dead plants $(p>0.05)$ (Figure 2A). The lowest Ds of the surface layer observed were $1.03 \mathrm{Mg} \mathrm{m}^{-3}$ and $0.96 \mathrm{Mg} \mathrm{m}^{-3}$ in the area with living and that with dead plants, respectively. These values might have been related to soil management operation during forest implementation period. In addition, it could also be attributed to root density in the first layers and the higher biological activity up to 0.30 depth (Lipiecet al., 1991; Trevisan et al., 
2012). As the values of Ds increases, structure, arrangement, and pores volumes are modified and as a consequence water retention characteristics change (Stefanoski et al., 2013). However, considering the loamy texture, Brady and Weil (2010) pointed out that values from 1.20 to $1.80 \mathrm{Mg} \mathrm{m}^{-3}$ were restrictive limit to plant root growth, while Reichert et al. (2007) observed that the restrictive limit values were $1.91,1.93$ and $1.94 \mathrm{Mg}$ $\mathrm{m}^{-3}$ at $0-0.10,0.10-0.20$ and $0.20-0.40 \mathrm{~m}$ depths, respectively. Even so, values obtained in this study at all depths and areas were lower than the critical limits found in the literature (Arshad et al., 1996; Reichert et al., 2007).

In forest systems, surface Ds increase may be related to the period of area usage, low soil cover during plant initial growth period, machinery traffic and agricultural implements. Furthermore, soil moisture conditions during pre-planting operations and seedlings transplantation can contribute to Ds increase (Costa et al., 2003).

A.

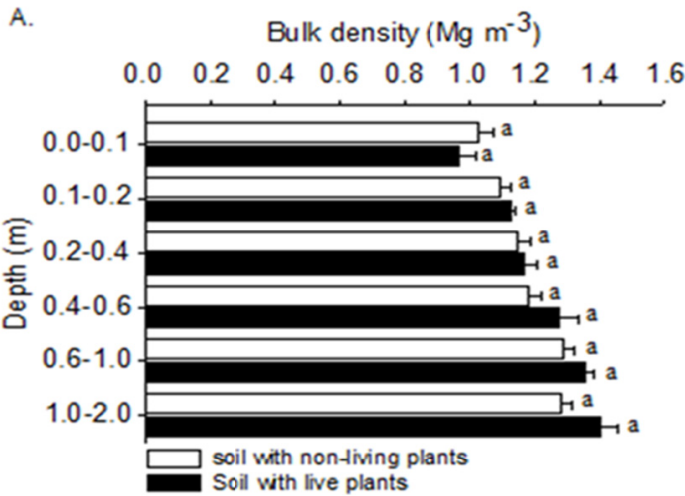

B. Total porosity $\left(\mathrm{m}^{3} \mathrm{~m}^{-3}\right)$

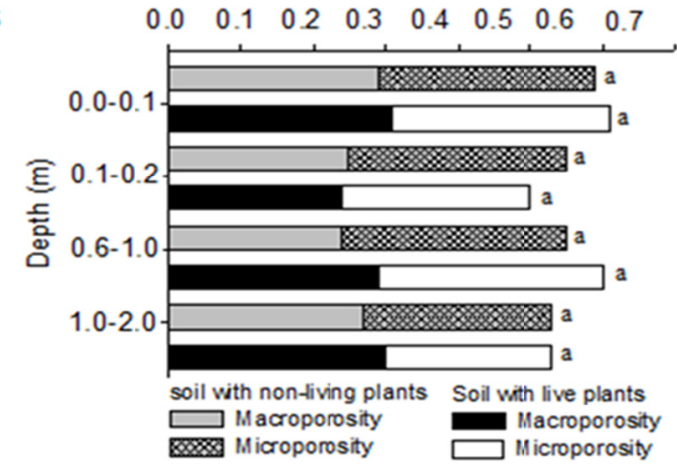

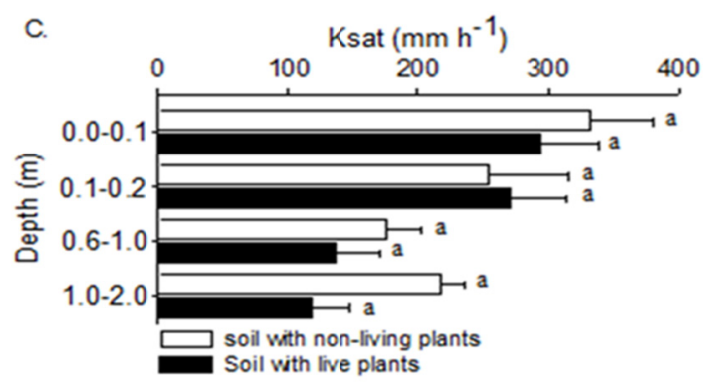

Figure 2. Bulk density (A), total porosity (B) and saturated hydraulic conductivity (Ksat) (C) in areas with dead and living plants with Eucalyptus spp. three years after planting in Regeneration, PI, city

Soil total porosity (TP) of the area with living plants was similar to that of the area with dead plants $(\mathrm{p}>0.05)$ (Figure 2B). TP values varied from $\approx 0.63 \mathrm{~m}^{3} \mathrm{~m}^{-3}$ at $0.10-0.20 \mathrm{~m}$ depth to $0.68 \mathrm{~m}^{3} \mathrm{~m}^{-3}$ at the last soil layer $(0.0$ $-0.10 \mathrm{~m}$ ) in the area with dead plants. In the area with living plants, it was found values of $0.58 \mathrm{~m}^{3} \mathrm{~m}^{-3}$ and 0.70 $\mathrm{m}^{3} \mathrm{~m}^{-3}$ in lowest and upper soil layers, respectively. TP highest value achieved at $0-0.10 \mathrm{~m}$ depth in the area with living plants may be justified by the lowest Ds value at this same depth $\left(0.96 \mathrm{Mg} \mathrm{m}^{-3}\right)$. Total porosity is a dependent attribute of soil components and is related to its density (Sperandio \& Cecílio, 2017).

Ksat values for both areas were not different in any evaluated depths (Figure $2 C)(p>0.05)$. The highest Ksat value was observed in the upper layer and decreased with the depth. The values ranged from 331 to $218 \mathrm{~mm} \mathrm{~h}^{-1}$ and 294 to $118 \mathrm{~mm} \mathrm{~h}^{-1}$ in the area with dead and in the area with living plants, respectively. Ksat values from 36 to $360 \mathrm{~mm} \mathrm{~h}^{-1}$ are considered high and the values over $360 \mathrm{~mm} \mathrm{~h}^{-1}$ are seen as very high (Soil Survey Staff, 2014). Therefore, the values observed in this study were considered high. The Ksat of a soil is dependent of the shape and pore continuity filled with water. The highest Ksat values are found in soils with higher total porosity (Mesquita \& Moraes, 2004). Nevertheless, Bouma (1982) describes that soil profiles presenting pore continuity, even tinier pores, can present high Ksat, while bigger pores at a given section may not assure an increase of soil water flux if there is pore discontinuity.

Based on the soil water retention curve (WRC), it was possible to have higher water drainage in the superficial layers (0-0.10 and $0.10-0.20 \mathrm{~m})$ in both areas. This behavior may be related to a majority of macropores, especially at the two first layers. According to Menezes and Pejon (2010), the air pressure entrance when achieved implies the beginning of bigger pores leakage (drainage process). And also, gravitational force remains 
under potentials lower than the field capacity $(-10 \mathrm{kPa})$. Regarding WRC, there were no difference between the two areas studied at the depths of 0.60 to $1.00 \mathrm{~m}$ (Figures $3 \mathrm{E}$ and $3 \mathrm{~F}$ ) and 1.00 to $2.00 \mathrm{~m}$ (Figures $3 \mathrm{G}$ and $3 \mathrm{H}$ ) $(\mathrm{p}>0.05)$.

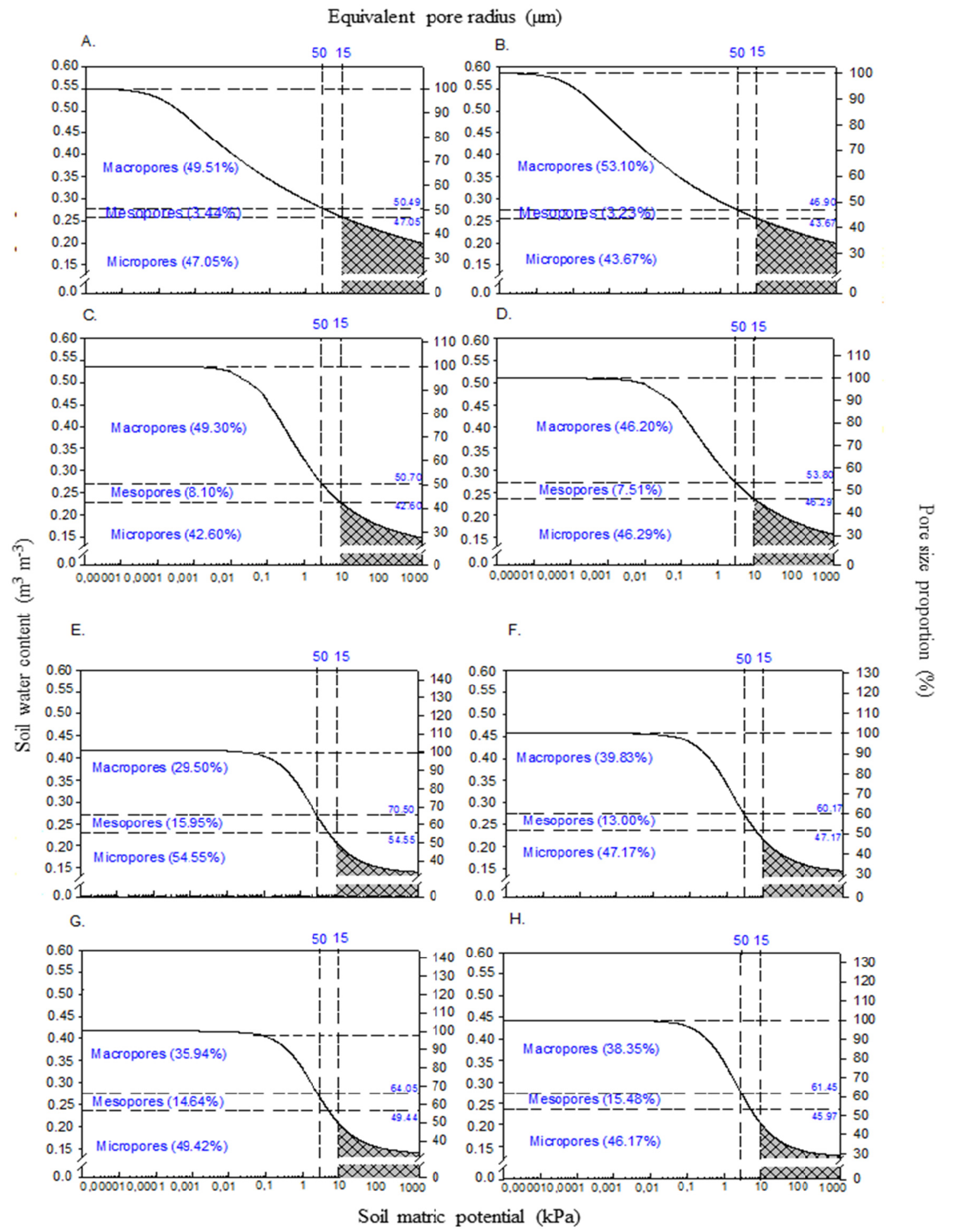

Figure 3. Soil water retention curve, available water and pore size distribution in areas of dead and living plants

Eucalyptus spp. three years after planting in Regeneração city. A and B: areas with dead and living plants, respectively, in the 0-0.10 m layer; $C$ and $D$ : areas with dead and living plants, respectively, in the $0.10-0.20 \mathrm{~m}$ layer; E and F: areas with dead and living plants, respectively, in the layer of 0.60 to $1.0 \mathrm{~m}$; $\mathrm{G}$ and $\mathrm{H}$ : areas with dead and living plants, respectively, in the layer of $1.0-2.0 \mathrm{~m}$ 
High porosity values in the surface depth stands for easily drainable water which is more important than the moisture content to be close to the permanent wilting point $(-1500 \mathrm{kPa})$, as higher value of humidity in this gap means more water available to plants (Klein \& Libardi, 2002). Water content at $-10 \mathrm{kPa}$ and $-1500 \mathrm{kPA}$ potential presented values similar in the areas with dead and living plants for all analyzed layers.

The pore distribution not differ from both areas studied (Figure 3) $(p>0.05)$. However, two classes of pores were observed, the first one with big pores provided quickly soil internal drainage and the second presenting tiny pores were related to the water retention with high energy (Klein \& Libardi, 2002). At the two surface layers macropores prevailed as the higher water content were available to the plants (represented by the gray color in the Figure 3). As the increase of depth, the second layer of 0.10-0.20 m (Figures 3C and 3D) recorded an increase of mesopores. In the 0.60-1.00 m depth layer (Figures 3E and 3F) and 1.00-2.00 m depth layer (Figures $3 \mathrm{G}$ and $3 \mathrm{H}$ ), mesopores increaseds when compared to the surface layers and micropores prevailed at the expense of macropores. Besides the abundance of micropores, the pore distribution evaluated along the profile, also presented higher values of Ksat in surface layers and that decreased along with the depth (Figure 2C) due to the reduction of macropores as depth increased.

Available water capacity (WRC) did not differ between the two areas studied (with dead palnts and with living plants) for each of the soil layers ( $p>0.05$ ) (Figure 4).

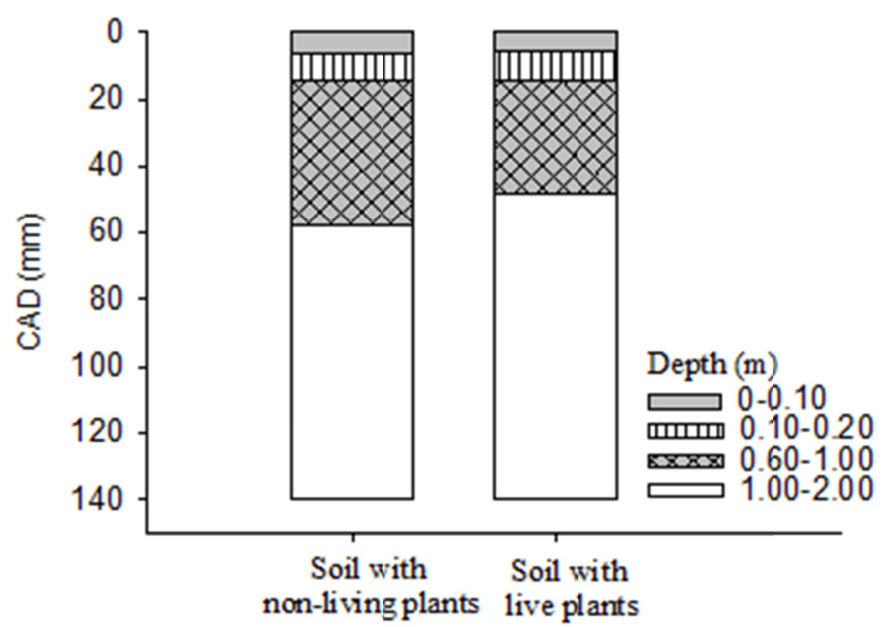

Figure 4. Available water capacity (WRC) of the soil with dead and living plants of Eucalyptus spp. after three years of planting in the studied areas

The 0-0.10 m-layer of the area with dead trees and 0.10-0.20 m-layer of the area with living trees recorded 6.08 $\mathrm{mm}$ and $5.45 \mathrm{~mm}$ of WRC, respectively. The low values of WRC may be related to the presence of bigger pores in the first layers (Figures 3A-3D). The greater variations in soil water storage could have occurred in the upper layers due an increase of water dynamics resulting from the disturbance of the soil structure.

At 0.20-0.60 m-layer of the area with dead trees and 0.60-1.00 m-layer of the area with living trees, WRC values were $43.34 \mathrm{~mm}$ and $33.71 \mathrm{~mm}$, respectively. Therefore, it was noted that, WRC values in these layers were higher than that of the above0mentioned upper layers. WRC values at 1.00-2.00 m depth were $82.27 \mathrm{~mm}$ and $91.69 \mathrm{~mm}$ in the areas with dead and living plants which did not differ significantly $(\mathrm{p}>0.05)$.

WRC values usually range from 150 to $300 \mathrm{~mm}$ in cultivated soils with forest species (Pereira et al., 2002). After performing the potential zoning to Eucalyptus crop production, WRC values of $220 \mathrm{~mm}$ were found in an Oxisol in the state of Minas Gerais (Guimarães et al., 2007). The above WRC values were higher than those found in this study i.e. 140.33 and $139.79 \mathrm{~mm}$ in the areas with dead and living plants for the same soil textural classification and depth. However, planting age and clones used could have contributed to a lower or higher soil water extraction by the Eucalyptus crop (Mello et al., 1998). In Eucalyptus crop with three years old, Stape \& Gomes (1996) found WRC value of $200 \mathrm{~mm}$, but it ranged from 37.07 to $238.48 \mathrm{~mm}$ in Eucalyptusstand of the same age but different genetic background (Reis et al., 2014).

In this study, Eucalyptus main root was found at depths greater than $3.00 \mathrm{~m}$. At $3 \times 2 \mathrm{~m}$ spacing between trees, the soil volume occupied by the roots was $18 \mathrm{~m}^{3}$. In this case, it was worth mentioning that ETo was $6.00 \mathrm{~mm}$, 
according to the daily average of 10 years based on the INMET database, to the study site. $\mathrm{K}_{\mathrm{c}}$ was 0.82 for Eucalyptus crop with three or four years old (Alves et al., 2013), and the crop daily evapotranspiration was 4.9 $\mathrm{mm}$ day $^{-1}$. As the total WRC value was 140.33 and $139.79 \mathrm{~mm}$ to the areas with dead and living plants, respectively, enough to sustain Eucalyptus trees for a maximum of 29 days after which they would have started experiencing soil water deficit. WRC valuesin the two areas studied were not statistically different $(p>0.05)$ suggesting that this attribute may not be the responsible for the death of the plants.

In reforested areas with Eucalyptus, Rodrigues et al. (2012) found that water was mainly stored upto $3.00 \mathrm{~m}$ depth, even though they also recorded plants death. Therefore, it was possible to affirm that the Eucalyptus plants death are associated with other factors.

The $\mathrm{S}$ index indicates soil structural quality and its relation with the root growth. In fact, an $\mathrm{S}>0.035$ indicates a preserved soil structure and favorable conditions to root growth, $\mathrm{S}<0.035$ indicates restrictive conditions, and $\mathrm{S}$ $<0.025$ denotes highly restrictive conditions to the development of plant roots (Dexter, 2004).
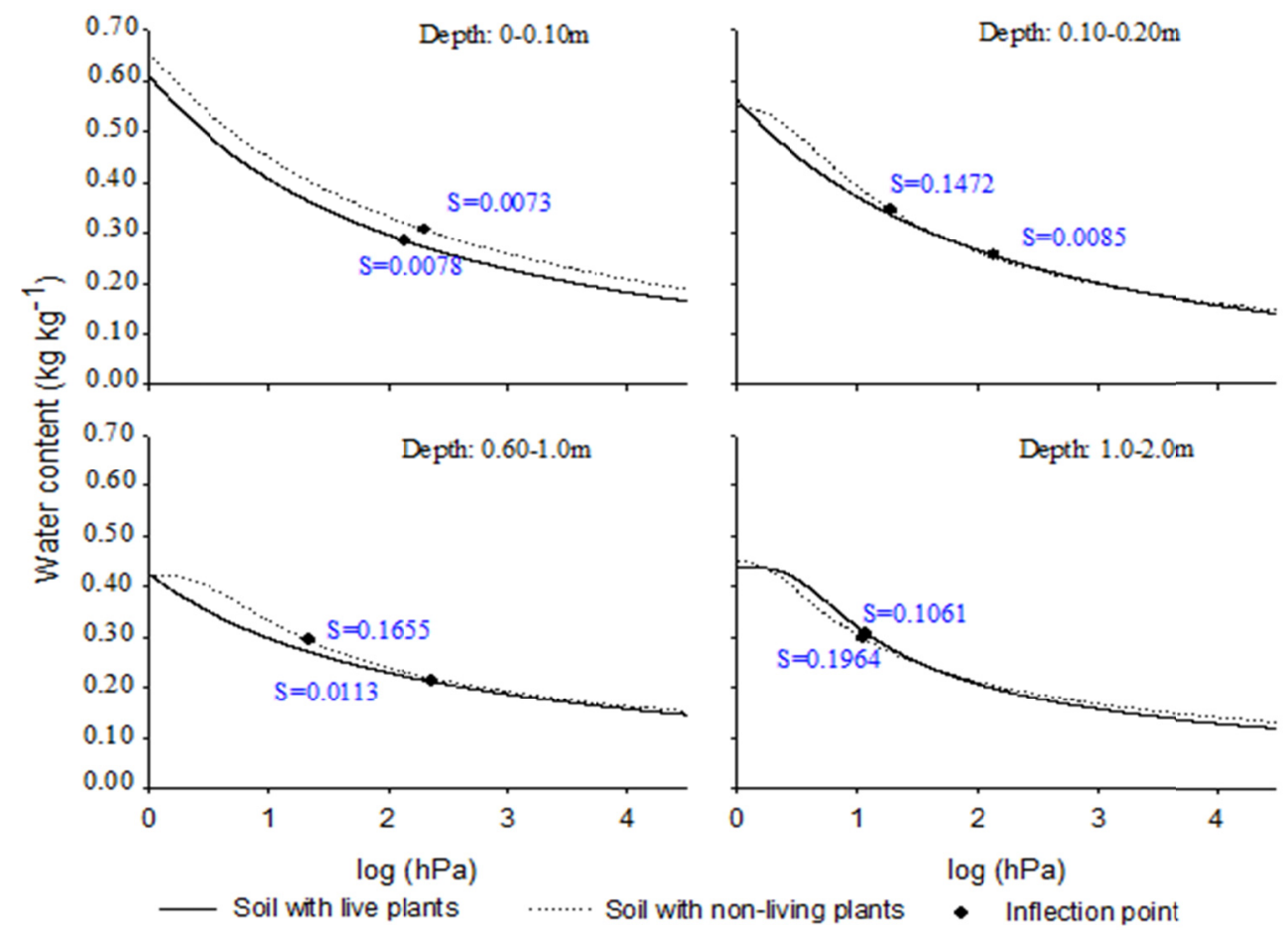

Figure 5. Dexter's S index in areas with dead and living plants of Eucalyptus spp. three years after the planting. A: areas with dead and living plants in the 0-0.10 m layer; B: Areas with dead and living plants in the 0.10-0.20 $\mathrm{m}$ layer; C: Areas with dead and living plants in the layer of 0.60 to $1.0 \mathrm{~m}$; D: Areas with dead and living plants in the layer of $1.0-2.0 \mathrm{~m}$

Both studied fields were classified as non-restrictive to the development of Eucalyptus plant (Figure 5) (p > $0.05)$. $\mathrm{S}$ values were 0.0078 and 0.0073 at the layer of $0-0.10 \mathrm{~m}$ to the areas with living and dead plants, respectively, while at $0.10-0.20 \mathrm{~m}$ depth, the $\mathrm{S}$ values were 0.0085 and 0.1472 for living and dead plants areas.

The low $\mathrm{S}$ value $(<0.020)$ observed at the layer $0.10-0.20 \mathrm{~m}$ in the area with living plants opposes to Martins et al. (2008) findings, which presented values of $\mathrm{S}>0.035$ in forest areas indicating a favorable soil structure to the development of plants due to pore geometry, minor mechanical restriction to the root growth and soil water retention characteristics. On the other hand, Oliveira (2010) evaluating the S index and relating with the Eucalyptus productivity, observed that some areas with low $\mathrm{S}$ value presented the highest productivity. Therefore, the author stated the need of testing hypothesis using this index in different soils and crops including Eucalyptus species.

Another point reviewed was that the $\mathrm{S}$ values proposed by Dexter (2004) were developed in Poland soils. Thus, Andrade and Stone (2009) suggested new S index values fitted to Brazilian cerrado soils. Although many works 
aimed at validating S index, Tormena et al. (2008) suggested that more studies must be conducted under different soils, land-use in the tropical conditions.

\section{Conclusion}

Soil bulk density (Ds), total porosity (TP), soil water retention curve (WRC), soil hydraulic conductivity (Ksat), available soil water capacity (WRC) and S index did not differentiate the area with dead Eucalyptus from the one bearing living species' trees. Both areas presented favorable physical and hydric soil conditions for developement of Eucalyptus spp. Therefore, there is a need of conducting more research on edafoclimatic conditions that can contribute to clarifying the reasons of the premature death of Eucalyptus trees.

\section{Acknowledgements}

This study was financed in part by the Coordenação de Aperfeiçoamento de Pessoal de Nível Superior-Brasil (CAPES)-Finance Code 001.

The authors thank Tiago Junqueira for making the Chapada Grande Farm available and Theo Kirk Leal for for all field research support.

\section{References}

Alves, M. E. B., Mantovani, E. C., Sediyama, G. C., \& Neves, J. C. L. (2013). Estimate of the crop coefficient for Eucalyptus cultivated under irrigation during initial growth. CERNE, 19(2), 247-253. https://doi.org/ $10.1590 / \mathrm{S} 0104-77602013000200008$

Andrade, R. da S., \& Stone, L. F. (2009). Índice S como indicador da qualidade física de solos do cerrado brasileiro. Revista Brasileira de Engenharia Agricola E Ambiental, 13(4), 382-388. https://doi.org/10.1590/ S1415-43662009000400003

Andrade Junior, A. S. de, Bastos, E. A., Silva, C. O. da, Gomes, A. A. N., \& Figueredo Júnior, L. G. M. de. (2011). Atlas climatológico do Estado do Piauí. Retrieved from https://www.infoteca.cnptia.embrapa.br/ handle/doc/885291

Arshad, M. A., Lowery, B., \& Grossman, B. (1996). Physical Tests for Monitoring Soil Quality. Methods for Assessing Soil Quality (Vol. 49, pp. 123-141). Soil Science Society of America. https://doi.org/10.2136/ sssaspecpub49.c7

Blake, G. R., \& Hartge, K. H. (1986a). Bulk Density. https://doi.org/10.2136/sssabookser5.1.2ed.c13

Blake, G. R., \& Hartge, K. H. (1986b). Particle Density. https://doi.org/10.2136/sssabookser5.1.2ed.c14

Bouma, J. (1982). Measuring the Hydraulic Conductivity of Soil Horizons with Continuous Macropores. Soil Science Society of America Journal, 46(2), 438. https://doi.org/10.2136/sssaj1982.036159950046000 $20047 \mathrm{x}$

Bouma, J., Jongerius, A., Boersma, O., Jager, A., \& Schoonderbeek, D. (1977). The Function of Different Types of Macropores During Saturated Flow through Four Swelling Soil Horizons. Soil Science Society of America Journal, 41(5), 945. https://doi.org/10.2136/sssaj1977.03615995004100050028x

Brady, N. C., \& Weil, R. R. (2010). The colloidal fraction: Seat of soil chemical and physical activity. Elements of The Nature and Properties of Soils. https://doi.org/10.5194/bg-8-1141-2011

Brazilian Tree Industry. (2017). Annual Report. Retrieved from https://www.iba.org/datafiles/publicacoe s/pdf/iba-relatorioanual2017.pdf

Costa, F. S., Albuquerque, J. A., Bayer, C., Fontoura, S. M. V., \& Wobeto, C. (2003). Propriedades físicas de um Latossolo Bruno afetadas pelos sistemas plantio direto e preparo convencional. Revista Brasileira de Ciência Do Solo. https://doi.org/10.1590/S0100-06832003000300014

Dexter, A. R. (2004). Soil physical quality: Part I. Theory, effects of soil texture, density, and organic matter, and effects on root growth. Geoderma, 120(3-4), 201-214. https://doi.org/10.1016/J.GEODERMA.2003.09.004

Fernandes, M. M., Carvalho, M. G. C., Araujo, J. M. R. de, Melo, F. R., Silva, C. A., Sampaio, F. de M. T., ... Lobato, M. G. R. (2012). Matéria Orgânica e Biomassa Microbiana em Plantios de Eucalipto no Cerrado Piauiense. Floresta E Ambiente, 19(4), 453-459. https://doi.org/10.4322/floram.2012.061

Gee, G. W., \& Bauder, J. W. (1986). Particle-size analysis in Methods of soil analysis, Part 1. Physical and mineralogical methods. American Society of Agronomy. 
Guimarães, D. P., Silva, G. G. C., Aguiar Sans, L. M., \& Leite, F. P. (2007). Uso do modelo de crescimento 3-PG para o zoneamento do potencial produtivo do eucalipto no estado de Minas Gerais. Revista Brasileira de Agrometeorologia, 15(2), 192-197.

Ibiapina, T. V. B., Salviano, A. A. C., Nunes, L. A. P. L., Mousinho, F. E. P., De Lima, M. G., \& Soares, L. M. dos S. (2014). Resistência à penetração e agregação de um Latossolo Amarelo sob monocultivo de soja e de eucalipto no cerrado do Piauí. Cientifica, 42(4), 411. https://doi.org/10.15361/1984-5529.2014v42n4 p411-418

INMET. (2017). The Brazilian National Institute of Meteorology. Retrieved from http://www.inmet.gov.br

Klein, V. A. \& Libardi, P. L. (2002). Densidade e distribuição do diâmetro dos poros de um latossolo vermelho, sob diferentes sistemas de uso e manejo. Revista Brasileira de Ciencia Do Solo, 26(4), 857-867. https://doi.org/10.1590/S0100-06832002000400003

Klute, A., Amoozegar, A., \& Warrick, A. W. (1986). Hydraulic Conductivity of Saturated Soils: Field Methods. https://doi.org/10.2136/sssabookser5.1.2ed.c29

Libardi, P. L. (2012). Dinâmica da água no solo (1st ed.). EDUSP.

Lipiec, J., Hakansson, I., Tarkiewicz, S., \& Kossowski, J. (1991). Soil physical properties and growth of spring barley as related to the degree of compactness of two soils. Soil and Tillage Research, 19(2-3), 307-317. https://doi.org/10.1016/0167-1987(91)90098-I

Lopes, C. R. (2013). Expansão da silvicultura de eucalipto no bioma cerrado: Uma análise sob a perspectiva dos fatores fisicos e socioeconômicos. Universidade Federal de Goiás, Brazil. Retrieved from https://repositorio.bc.ufg.br/tede/handle/tede/ 3250

Martins, F. B., Streck, N. A., Da Silva, J. C., Morais, W. W., Susin, F., Navroski, M. C., \& Vivian, M. A. (2008). Deficiência hídrica no solo e seu efeito sobre transpiração, crescimento e desenvolvimento de mudas de duas espécies de eucalipto. Revista Brasileira de Ciencia Do Solo. https://doi.org/10.1590/S0100-0683200 8000300037

Mello, S. L. de M., Gonçalves, J. L. de M., \& Oliveira, L. E. G. de. (1998). Características do sistema radicular em povoamentos de eucaliptos propagados por sementes e estacas. Scientia Florestalis, 54, 17-28.

Menezes, M. B. M., \& Pejon, O. J. (2010). Analysis of influence of moisture content on the absorption of water and soil suction in studies of erodibility. Geociencias.

Mesquita, M. da G. B. de F., \& Moraes, S. O. (2004). A dependência entre a condutividade hidráulica saturada e atributos físicos do solo. Ciência Rural, 34(3), 963-969. https://doi.org/10.1590/S0103-847820040 00300052

Oleriano, E. dos S., \& Dias, H. C. T. (2007). A dinâmica da água em microbacias hidrográficas reflorestadas com eucalipto. I Seminário de Recursos Hídricos da Bacia Hidrográfica do Paraíba do Sul: o Eucalipto e o Ciclo Hidrológico (pp. 215-222). Taubaté. Retrieved from https://s3.amazonaws.com/academia.edu.docum ents/34447601/215-222.pdf?AWSAccessKeyId=AKIAIWOWYYGZ2Y53UL3A\&Expires=1541289052\&S ignature=110Gujx 4tVcpvgGDgL2VsysR\%2FjI\%3D\&response-content-disposition=inline $\% 3 \mathrm{Bfilename \% 3}$ DA_dinamica_da_agua_em_microbacias_hi

Oliveira, A. P. de. (2010). Índice S e suas relações com características de solos e com a produtividade de eucalipto. Universidade Federal de Viçosa, Brazil. Retrieved from http://www.locus.ufv.br/handle/ $123456789 / 1612$ ? show=full

Pereira, A. R., Angelocci, L. R., \& Sentelhas, P. C. (2002). Agrometeorologia: Fundamentos e aplicações práticas. Guaíiba: Livraria e Editora Agropecuária.

Reichert, J. M., Suzuki, L. E. A. S., \& Reinert, D. J. (2007). Compactação do solo em sistemas agropecuários e florestais: identificação, efeitos, limites críticos e mitigação. Tópicos Ciência Solo (Vol. 5). Retrieved from http://fisicadosolo.ccr.ufsm.quoos.com.br/downloads/Prod ucao_Artigos/2007_Topicos.pdf

Reis, M. G. dos, Ribeiro, A., Baesso, R. C. E., Souza, W. G. de, Fonseca, S., \& Loos, R. A. (2014). Balanço hídrico e de energia para plantios de eucalipto com cobertura parcial do solo. Ciência Florestal, 24(1), 117-126. https://doi.org/10.5902/1980509813329

Reynolds, W. D., Elrick, D. E., Dane, J. H., \& Topp, G. (2002). Constant head soil core (tank) method. Methods of soil analysis (Part 4, pp. 804-808). 
Rodrigues, A., Paulo, Fenner, T., Cláudio, Sansigolo, A., \& Moraes, M. H. (2012). Estimativa da água no solo em floresta de Eucalyptus grandis (pp. 523-533). Retrieved from https://www.cabdirect.org/cabdirect/ FullTextPDF/2013/20133010798.pdf

Ryan, M. G., Stape, J. L., Binkley, D., Fonseca, S., Loos, R. A., \& Takahashi, E. N. (2010). Factors controlling Eucalyptus productivity: How water availability and stand structure alter production and carbon allocation. Forest Ecology and Management, 259(9), 1695-1703. https://doi.org/10.1016/j.foreco.2010.01.013

Santos, R. D. dos, Santos, H. G. dos, Ker, J. C., Anjos, L. H. C. dos, \& Shimizu, S. H. (2015). Manual de Descrição e Coleta de Solo no Campo. Viçosa: Sociedade Brasileira de Ciência do Solo.

Soil Survey Staff. (2014). In Natural Resources Conservation Service (Ed.), Keys to soil taxonomy (12th ed.). U.S. Department of Agriculture Handbook. Retrieved from https://www.nrcs.usda.gov/Internet/FSE_DOC UMENTS/nrcs142p2_051232.pdf

Souza, O. M. M., Collicchio, E., Pereira, E. Q. \& Azevedo, M. I. R. (2014). Zoneamento agroclimático para o Eucalyptus urograndis no Estado do Tocantins (pp. 231-239). Anais $5^{\circ}$ Simpósio de Geotecnologias no Pantanal. Campo Grande, MS: Embrapa Informática Agropecuária/INPE.

Sperandio, H. V., \& Cecílio, R. A. (2017). Atributos físicos do solo em área sob colheita florestal semimecanizada no estado do espírito santo. Revista Ciência Agrícola, 15(2), 69-74. https://doi.org/ 10.28998/rca.v15i2.3390

Stape, J. L., \& Gomes, A. N. (1996). Influência dos estresses hídricos e nutricionais no crescimento de plantios de eucaliptos no nordeste do Brasil. X Congresso Latino Americano de Ciência do Solo.

Stefanoski, D. C., Santos, G. G., Marchão, R. L., Petter, F. A., \& Pacheco, L. P. (2013). Uso e manejo do solo e seus impactos sobre a qualidade física. Revista Brasileira de Engenharia Agrícola E Ambiental, 17(12), 1301-1309. https://doi.org/10.1590/S1415-43662013001200008

Tormena, C. A., Silva, Á. P. da, Imhoff, S. D. C., \& Dexter, A. R. (2008). Quantification of the soil physical quality of a tropical oxisol using the S index. Scientia Agricola, 65(1), 56-60. https://doi.org/10.1590/ S0103-90162008000100008

Trevisan, R., Salemi, L., Groppo, J., Silva, R., Martinelli, L., \& Moraes, J. (2012). Dinâmica da Água em uma Microbacia com Cobertura Florestal de EucaliptoLocalizada na Serra do Mar no Vale do Paraíba do Sul. Revista Brasileira de Recursos Hidricos, 17(4), 207-216. https://doi.org/10.21168/rbrh.v17n4.p207-216

van Genuchten, M. T. (1980). A Closed-form Equation for Predicting the Hydraulic Conductivity of Unsaturated Soils. Soil Science Society of America Journal, 44(5), 892. https://doi.org/10.2136/sssaj1980.0361599500 4400050002x

Vose, J. M., \& Swank, W. T. (1994). Effects of long-term drought on the hydrology and growth of a white pine plantation in the southern Appalachians. Forest Ecology and Management, 64(1), 25-39. https://doi.org/ 10.1016/0378-1127(94)90124-4

\section{Copyrights}

Copyright for this article is retained by the author(s), with first publication rights granted to the journal.

This is an open-access article distributed under the terms and conditions of the Creative Commons Attribution license (http://creativecommons.org/licenses/by/4.0/). 